\title{
Antibacterial Activity of Cinnamaldehyde and Carvacrol against Foodborne Pathogens and Spoilage Bacteria
}

\author{
Shikha Rani Saha ${ }^{1}$, M.L. Bari², Y. Inatsu³, S. Kawampto ${ }^{3}$, and Md. Mahfuzul Hoque ${ }^{*}$ \\ ${ }^{1}$ Department of Microbiology, University of Dhaka, Dhaka-1000, Bangladesh, ${ }^{2}$ Center for Advanced Research in Sciences, University of Dhaka, Dhaka, 1000, \\ Bangladesh. ${ }^{3}$ National Food Research Institute, 2-1-12 Kannondai, Tsukuba, Ibaraki, 305-8642, Japan
}

\begin{abstract}
The excessive use of chemical preservatives is a serious problem worldwide, which necessitates the discovery of new classes of antimicrobials from other sources like herbs and spices for preservation of food and/or food products. In this study, antibacterial activity of essential oils (EOs) such as cinnamaldehyde and carvacrol were tested against four foodborne pathogens viz Staphylococcus aureus ATCC 25923, Shigella dysenteriae-I MJ-84, Escherichia soli ATCC 25922, Vibrio cholerae ATCC 6395 and two food spoilage bacteria viz Pseudomonas aeruginosa ATCC 27853 and Klebsiella rhizophila ATCC 13882, respectively, using disc diffusion method. These EOs were found to inhibit both categories of bacteria. Cinnamaldehyde and carvacrol showed maximum $30.0 \pm 0.2$ and $27.5 \pm 0.5$ zones of inhibition, respectively against $S$. aureus. Pseudomonas aeruginosa was found resistant against carvacrol. Cinnamaldehyde and carvacrol was determined. Both showed antibacterial activity after treatment at $100^{\circ} \mathrm{C}$ for 30 min suggesting that high temperature does not affect the activity. Both the EOs have a broad $\mathrm{pH}$ range and exhibited highest activity at $\mathrm{pH} 7.0$, suggesting that they remain un-dissociated at $\mathrm{pH}$ change. The MIC and MBC values of cinnamaldehyde ranged between 0.125 and $.0 \%$, and 0.25 and $2.0 \%$, respectively and MIC and MBC values of carvacrol ranged between 0.125 and $0.5 \%$, and 0.25 and $1.0 \%$, respectively. The results of this study confirmed the possibility of using cinnamaldehyde and carvacrol in preventing the growth of foodborne pathogens and spoilage bacteria and extend the shelf life of foods.
\end{abstract}

Key note: Antibacterial activity, cinnamaldehyde, carvacrol, foodborne pathogens, spoilage bacteria

\section{Introduction}

Worldwide it is considered that foodborne diseases are mainly caused by foodborne pathogens either by infection and/or by intoxication and frequently reported potent pathogens are Staphylococcus aureus, Salmonella spp., Escherichia spp. (Various serotypes), and Bacillus cereus ${ }^{1}$. Short shelf life of food products due to spoilage is one of the major problems of the food industry, which includes mainly Pseudomonas aeroginosa, Bacillus subtilis, and Alcaligenes faecalis etc. ${ }^{2,3}$.

Food poisoning caused by Listeria monocytogenes, Staphylococcus aureus, Salmonella sp. B. cereus, Aeromonas spp. and Escherichia coli 0157:H7 is worldwide serious problem, especially in developing countries. It has been reported that, among the various diarrheagenic serotypes, enterohemorrhagic E. coli $0157: \mathrm{H} 7$ is implicated in large number of food borne outbreaks in many parts of the world ${ }^{4}$. Shigella dysenterae and $V$. cholerae are serious problem in Bangladesh. It is the most virulent Shigella with low infectious dose, high attack rate, and high mortality. Vibrio cholerae, 0139, spread rapidly in Bangladesh, producing disease in adults as well as children. It is mainly food and water borne pathogen but can survive for prolong time in water, possibly in blue-green algae and replicating in finfish and shellfish ${ }^{5}$.
Food preservation by chemical preservatives for quality food is now global concern, because chemical preservatives at high concentration are health hazardous, for which food safety has recently led to the development of natural antimicrobials to control foodborne pathogens and spoilage bacteria. Essential oils from spices, and antimicrobials from plants and herbs may be the alternative of the chemical preservatives, because of their ability to inhibit the growth of both Gram positive and Gram negative foodborne pathogens and spoilage bacteria ${ }^{6-16}$. Thymol, cinnamon oil and carvacrol have previously been demonstrated as a broad spectrum antimicrobials ${ }^{17,18}$.Cinnamaldehyde, thymol, carvacrol and eugenol were most active against $E$. coli serovars, Salmonella enterica and L. monocytogenes ${ }^{19}$. Essential oils from cloves and cinnamon can kill all cells of E. coli $\mathrm{O} 157: \mathrm{H} 7$ and Listeria monocytogenes in vivo within 60 minutes ${ }^{8,20}$. Cinnamaldehyde ${ }^{8,21,22}$ and carvacrol ${ }^{23,-25}$ are recognized as a potent growth inhibitor of common foodborne pathogens and spoilage bacteria.

The objective of this study is to assess i) Screening of the cinnamaldehyde and carvacrol for antibacterial activity against food borne pathogens and spoilage bacteria, ii) Determination of the effect of temperatures and $\mathrm{pH}$ on antibacterial activity of these essential oils, and iii) Determination of the Minimum 
Inhibitory Concentration (MIC) and Minimum Bactericidal Concentration (MBC) of these essential oils.

\section{Materials and Methods}

\section{Essential oils}

Cinnamaldehyde and carvacrol (EOs) wwere used in this study. Cinnamaldehyde was purchased from Nacalai Tesque, Co (Kyoto, Japan) and carvacrol from Wako Pure Chemical Industries Limited (Osaka, Japan).

\section{Reference strain}

Total 6 strains of food borne pathogens were used in the study (Table 1). Of the 6 organisms studied, first 4 were food borne pathogens and the rest of 2 were food spoilers. The long-term stock cultures of the test organisms in $20 \%$ glycerol in cryogenic vials were kept at $-70^{\circ} \mathrm{C}$. Working cultures were kept at $4^{\circ} \mathrm{C}$ on Trypto Soy Agar (TSA) slants and were periodically transferred to fresh slants.

Table 1. Test organisms used in this study

\begin{tabular}{lcc}
\hline Organisms & No. of type culture & Source \\
\hline Staphylococcus aureus & ATCC 25923 & ICDDR'B \\
Vibrio cholerae & ATCC 6395 & ICDDR'B \\
Escherichia coli & ATCC25922 & Shishu Hospital \\
Shigella dysenterae & MJ-84 & University of Dhaka \\
Pseudomonas aeroginosa & ATCC 27853 & Shishu Hospital \\
Klebsiella rhizoplila & ATCC 13882 & Shishu Hospital \\
\hline
\end{tabular}

Media used

Mueller-Hinton Agar (MHA) (Dickinsm and Company, France), Trypto Soya Agar (TSA) (NISSUI, Japan), Mueller-Hinton Broth (MHB) (Becton, Dickinsm and Company, France).

\section{Standard antibiotics}

Antibiotic and its disc potency used was gentamycin $(10 \mu \mathrm{g})$ (NISSUI Pharmaceuticals Co. Ltd. Japan).

\section{Preparation of stock solutions of essential oils}

The crude sample contained $100 \%$ cinnamaldehyde and carvacrol, from which $10 \%$ stock solution of cinnamaldehyde and carvacrol was made with $95 \%$ ethanol. The stocks were made aliquot in $5 \mathrm{ml}$ volumes and kept at refrigeration temperature until use.

\section{Impregnation of filter paper discs}

Discs ( $8 \mathrm{~mm}$ in diameter) made of Whatman filter paper no, I (ADVANTEC; Toyo Roshi Kaisha Ltd., Japan) were impregnated with $50 \mu$ of each $3 \%$ cinnamaldehyde and carvacrol made from $10 \%$ stock solutions and were then dried at $40^{\circ} \mathrm{C}$ for 1 hour in hot air oven (Barnstead Labline, USA) and were stored at $4{ }^{\circ} \mathrm{C}$ until use. Negative control (without the essential oil) was prepared in $95 \%$ ethanol.

\section{Preparation of inocula}

One loopful of inoculum of each test organism from cryogenic vial was transferred into $9 \mathrm{ml}$ of sterile Trypto Soya Broth (TSB) and grown at $37^{\circ} \mathrm{C}$ for 24 hours. One loopful of the TSB culture was then streaked into the TSA plate and grown at $37^{\circ} \mathrm{C}$ for 24 hours. The inocula of the test organisms were prepared by transferring 3 to 4 colonies of the cultures on TSA into $9 \mathrm{ml}$ of sterile MHB and incubated at $37^{\circ} \mathrm{C}$ for 5-6 hours, if necessary $12 \mathrm{~h}$ to $18 \mathrm{~h}$ was considered. The MHB culture was compared with McFarland 0.5 turbidity standards $\left(10^{8} \mathrm{CFU} / \mathrm{ml}\right)^{26}$

\section{Preparation of the McFarland standard}

$0.05 \mathrm{ml}$ of $0.048 \mathrm{M} \mathrm{BaCl}_{2}$ was added to $9.95 \mathrm{ml}$ of $0.18 \mathrm{M}$ $\mathrm{H}_{2} \mathrm{SO}_{4}$ in a test tube with constant stirring. The tube was then sealed tightly and stored in the dark at room temperature.

\section{Inoculation of inoculated plates}

After adjusting the turbidity of the inoculum suspension, a sterile cotton swab was dipped into the adjusted suspension. The swab was rotated several times and pressed firmly on the inside wall of the tube above the fluid level. The dried surface of a MuellerHinton agar plate was inoculated by streaking the swab over the entire sterile agar surface. This procedure was repeated by streaking two more times, rotating the plate approximately $60^{\circ}$ each time.

\section{Application of discs to inoculated agar plates}

The essential oil impregnated discs were dispensed onto the surface of the inoculated agar plate. Each disc was pressed down to ensure complete contact with the agar surface. For each plate 5 discs were placed. Discs for negative control were prepared using the same solvent without the essential oil. The plates are inverted and placed in an incubator at $37^{\circ} \mathrm{C}$ for 24 hours.

\section{Evaluation of antibacterial activity}

Antibacterial activity was evaluated by measuring the zones of inhibition in $\mathrm{mm}$ (including the $8 \mathrm{~mm}$ disc) with slide calipers near the agar surface and the results were recorded. The endpoint was taken as complete inhibition of growth as determined by the naked eye. Each essential oil was tested in triplicates and assay in this experiment was repeated thrice.

\section{Effect of temperature on antimicrobial activity of essential oils}

The effects of temperature on antibacterial activity of essential oils were determined by the methods as described by Lee ChingFu el al., $(2004)^{27}$.

The vials with the essential oil and the negative control were incubated in water bath set at $25,37,50,75$, and $100{ }^{\circ} \mathrm{C}$, respectively for $30 \mathrm{~min}$. After the temperature treatment, the antibacterial activity of the cinnamaldehyde and carvacrol was carried out against the test organisms (4 food borne pathogen and 2 food spoiler). The antibacterial activity was assayed by the disc diffusion methods by Bauer et al. (1966) ${ }^{28}$. 


\section{Effect of $\mathrm{pH}$ on antibacterial activity of essential oils}

The effect of $\mathrm{pH}$ on the antibacterial activities of cinnamaldehyde and carvacrol were assayed by using methods reported previously with slight modification ${ }^{29,30}$. The buffer solutions used were 50 $\mathrm{mM}$ citrate buffer ( $\mathrm{pH} 7.0$ ), $50 \mathrm{mM}$ Phosphate buffer ( $\mathrm{pH} 7.0$ ) and $20 \mathrm{mM}$ Tris-HC1 buffer ( $\mathrm{pH} 9.0)$. All the buffers were sterilized through $0.45 \mu \mathrm{m}$ of membrane filter, stored at $4^{\circ} \mathrm{C}$ and used within $30 \mathrm{~min}$. The $\mathrm{pH}$ of the essential oil was determined with sterile $\mathrm{pH}$ paper strip. At $10 \%$ concentration, $\mathrm{pH}$ of the cinnamaldehyde was 5.0 and for carvacrol it was 6.0.

The discs impregnated with $50 \mu 1$ of $3 \%$ cinnamaldehyde were then placed on the MHA plates previously seeded with the test organisms ${ }^{28}$. Negative controls were prepared using the different buffer solution without the essential oil. Three discs with the same $\mathrm{pH}$ were placed on each plate. The plates were kept at $4^{\circ} \mathrm{C}$ for 30 min for better absorption of the sample and then inverted and placed in an incubator set to $37^{\circ} \mathrm{C}$ for 24 hours. Antibacterial activity was evaluated by measuring the zones of inhibition in $\mathrm{mm}$ (including the $8 \mathrm{~mm}$ disc) for different $\mathrm{pH}$ with slide calipers near the agar surface and the results were recorded. Each essential oil was tested in triplicates.

\section{Determination of the MIC and MBC of essential oils}

The MIC of cinnamaldehyde and carvacrol was determined by tube dilution techniques in MHB medium ${ }^{31}$. The range of concentration for cinnamaldehyde and carvacrol used was 4$0.0625 \%(\mathrm{v} / \mathrm{v})$. The $\mathrm{MIC}$ was done at $37^{\circ} \mathrm{C}$ and at optimum $\mathrm{pH}$ 7.0. 'Stock solutions of the cinnamaldehyde and carvacrol were diluted in $50 \mathrm{mM}$ phosphate buffer $(\mathrm{pH} 7.0)$ to make concentrations of $8 \%$. Further dilutions for the MIC / MBC were done by the two fold dilution method in the buffer to make $4 \%$, $2 \%, \mathrm{I} \%, 0.5 \%, 0.25 \%, 0.125 \%$ and $0.0625 \%$.

$0.9 \mathrm{ml}$ of the MHB was taken in each of the sterile and dry glass vials appropriately labeled with concentrations of cinnamaldehyde and carvacrol. $1.0 \mathrm{ml}$ of the respective essential oil concentrations was dispensed into the respective vials and $100 \mu \mathrm{l}$ of the each test organisms were added to the vials with their names labeled to make sure that each of the organisms faced a different concentration of the cinnamaldehyde and carvacrol. So, the final reaction volume became $2 \mathrm{ml}$. A positive control was made with MHB and sterile distilled water plus culture of test organisms. A negative control was made with essential oil and MHB but no test organisms. All the prepared vials were then incubated at $37^{\circ} \mathrm{C}$ for 24 hours. For determination of MIC or $\mathrm{MBC}, 10 \mu \mathrm{l}$ inoculum from each test vial was transferred onto MHA plate and incubated at $37^{\circ} \mathrm{C}$ for 24 hours.

\section{Statistical analysis}

The inhibition zones were calculated as means \pm S.D. $(n=3)$. The significance among different data was evaluated by analysis of variance (ANOVA) using Microsoft excel program. Significant differences in the data were established by least significant difference at the $5 \%$ level of significance.

\section{Results}

Screening of the antibacterial activity of essential oil

Antibacterial activity of cinnamaldehyde and carvacrol are summarized in Tables 2. Cinnamaldehyde showed better inhibitory activity against the 6 selected food borne pathogens and spoilage bacteria with zones of inhibition ranged between 14.5 and $30.0 \mathrm{~mm}$ with maximum zone of inhibition for $S$. aureus $(30.0 \mathrm{~mm})$ which was larger than gentamycin $(10 \mu \mathrm{g} / \mathrm{disc})$ and minimum for Pseudomonas aeruginosa $(14.5 \mathrm{~mm})$.

Carvacrol was found to be active against all the test organisms except Pseudomonas aeruginosa with zones of inhibition ranged between 21.0 and $27.5 \mathrm{~mm}$. Carvacrol showed maximum zone of inhibition for S. aureus $(27.5 \mathrm{~mm})$, which was larger than those observed against the antibiotic tested.

\section{Effect of temperature on antibacterial activity of essential oils}

The effect of the temperatures on the antibacterial activity of cinnamaldehyde and carvacrol against all the test bacteria were shown in Table 3. The antibacterial activity of cinnamaldehyde and carvacrol was found at all temperatures employed $\left(25^{\circ}, 37^{\circ}\right.$, $50^{\circ}, 75^{\circ}$ and $100^{\circ} \mathrm{C}$ ), suggesting that cinnamaldehyde and carvacrol were not destroyed at high temperature even at $100^{\circ} \mathrm{C}$ for $30 \mathrm{~min}$ treatment. Moreover, the antibacterial activities were found to increase with the increasing temperature. Highest activity was found at $100{ }^{\circ} \mathrm{C}$ and lowest activity was found at $50{ }^{\circ} \mathrm{C}$ for the test bacteria.

All the values are mean \pm standard deviation of three determinations. Mean \pm S.D. $\mathrm{mm}(\mathrm{n}=3)_{;} \mathrm{P}<0.05$

Effect of pH on antibacterial activity of cinnamaldehyde and carvacrol

The antibacterial activity was not affected at $\mathrm{pH} 5.0$, and no significant decrease in inhibition was found (Table 4). The $\mathrm{pH}$ 7.0 and 9.0 enhanced the antibacterial activities of cinnamaldehyde and carvacrol against most of the organisms tested, where the highest activities were found at $\mathrm{pH}$ 7.0(Table 4). Both the EOs showed the higher activity against $S$. aureus at pH 7.0 compared to $\mathrm{pH} 5.0$ and 9.0.

\section{MIC and MBC of cinnamaldehyde and carvacrol}

MIC values of cinnamaldehyde against the test bacteria ranged between $0.125 \%$ and $1.0 \%(0.25$ and $2.0 \% \mathrm{MBC})$ and for carvacrol 0.125 to $0.5 \%,(0.25$ and $1.0 \mathrm{MBC})$ (Table 5).

The MIC of cinnamaldehyde showed the highest inhibition for $S$ .aureus $(0.125 \%)$ and followed by K. rhizophila $(0.25 \%)$ and $V$. cholerae $(0.25 \%)$. However, lowest MIC value was found for $P$. aeruginosa (1\%). The MIC of carvacrol showed the highest inhibition $S$. aureus $(0.125 \%)$ and followed by $S$. dysentarae $(0.25 \%)$, K. rhizophila $(0.25 \%)$ and $V$. cholerae $(0.25 \%)$. 
Table 2. The screening of antibacterial activities of cinnamaldehyde (Cinn) and carvacrol (Carv)

\begin{tabular}{lccc}
\hline Organisms & \multicolumn{3}{c}{ Zones of inhibition (mm) } \\
\cline { 2 - 4 } & Cinn (3\%) & Carv (3 \%) & Gentamycin(I 0 $\mu$ g/disc) \\
\hline Staphylococcus aureus & $30.0 \pm 0.2$ & $27.5 \pm 0.5$ & $23.5 \pm 1.0$ \\
Vibrio cholerae INC2 & $26.5 \pm 1.0$ & $26.0 \pm 0.45$ & $24.0 \pm 0.64$ \\
Escherichia coli & $27.0 \pm 0.1$ & $21.0 \pm 0.6$ & $21.0 \pm 0.42$ \\
Shigella dysenteriae -1 & $24.0 \pm 0.8$ & $22.5 \pm 1.12$ & $24.0 \pm 1.1$ \\
Pseudomonas aeruginosa & $14.5 \pm 0.2$ & Resistant & $26.5 \pm 0.18$ \\
Klebsiella rhizophila & $29.5 \pm 0.4$ & $24.2 \pm 0.09$ & $28.0 \pm 0.50$ \\
\hline
\end{tabular}

Mean \pm S.D. $m m(n=3), P<0.05$

Table 3. Effect of temperatures on antibacterial activity of cinnamaldehyde (Cinn.) and carvacrol (Carv.) at $3 \%$ concentration

\begin{tabular}{|c|c|c|c|c|c|c|c|c|c|c|}
\hline & \multicolumn{10}{|c|}{$\begin{array}{l}\text { Zones of inhibition }(\mathrm{mm}) \\
\text { Temperatures }\end{array}$} \\
\hline & \multicolumn{2}{|c|}{$25^{\circ} \mathrm{C}$} & \multicolumn{2}{|c|}{$37^{\circ} \mathrm{C}$} & \multicolumn{2}{|c|}{$50^{\circ} \mathrm{C}$} & \multicolumn{2}{|c|}{$75^{\circ} \mathrm{C}$} & \multicolumn{2}{|c|}{100} \\
\hline & Cinn & Carv. & Cinn & Carv. & Cinn & Carv. & Cinn & Carv & Cinn & Carv. \\
\hline Vibrio cholerae & $25.0 \pm 0.8$ & $24.5 \pm 0.8$ & $27.0 \pm 1.0$ & $26.0 \pm 1.0$ & $23.2 \pm 0.5$ & $22.0 \pm 0.5$ & $27.0 \pm 0.1$ & $26.0 \pm 0.1$ & $28.0 \pm 0.3$ & $27.3 \pm 03$ \\
\hline Escherichia coli & $22.0 \pm 0.3$ & $18.5 \pm 0.3$ & $25.0 \pm 0.7$ & $21.0 \pm 0.7$ & $22.2 \pm 0.6$ & $17.0 \pm 0.6$ & $24.3 \pm 0.2$ & $22.5 \pm 0.2$ & $26.0 \pm 0.1$ & $24.0 \pm 0.1$ \\
\hline Pseudomonas aeruginosa & $11.9 \pm 1$ & $\mathrm{R}$ & $13.8 \pm 0.2$ & $\mathrm{R}$ & $11.0 \pm 0.1$ & $\mathrm{R}$ & $14.5 \pm 0.2$ & $\mathrm{R}$ & $16.0 \pm 0.6$ & $\mathrm{R}$ \\
\hline Klebsiella rhizophila & $24.2 \pm 0.4$ & $23.0 \pm 0.4$ & $28.5 \pm 0.7$ & $24.0 \pm 0.7$ & $22.3 \pm 0.2$ & $21.5 \pm 0.2$ & $27.5 \pm 0.4$ & $25.5 \pm 0.4$ & $29.5 \pm 0.1$ & $27.0 \pm 0.1$ \\
\hline
\end{tabular}

Table 4. Effect of pH on antibacterial activity of cinnamaldehyde (Cinn) and carvacrol (Carv) at $3 \%$ concentration

\begin{tabular}{|c|c|c|c|c|c|c|}
\hline \multirow[t]{2}{*}{$\overline{\text { Organisms }}$} & \multicolumn{6}{|c|}{$\begin{array}{c}\text { Zones of inhibition (mm) } \\
\text { pH }\end{array}$} \\
\hline & \multicolumn{2}{|c|}{5.0} & \multicolumn{2}{|c|}{7.0} & \multicolumn{2}{|c|}{9.0} \\
\hline$\overline{\text { Staphylococcus aureus }}$ & $25.0 \pm 1.0$ & $23.0 \pm 0.2$ & $29.6 \pm 0.57$ & $26.5 \pm 0.6$ & $28 \pm 0.1$ & $24.3 \pm 1.0$ \\
\hline Vibrio cholerae & $24.0 \pm 10$ & $21.5 \pm 0.5$ & $27.3 \pm 0.57$ & $24.0 \pm 0.57$ & $26.8 \pm 0.4$ & $22.8 \pm 0.4$ \\
\hline Pseudomonas aeruginosa & $13.8 \pm 0-5$ & $\mathrm{R}$ & $14.5 \pm 1.0$ & $\mathrm{R}$ & $15.3 \pm 1.1$ & $\mathrm{R}$ \\
\hline Klebsiella rhizophila & $21.2 \pm 0-7$ & $21.5 \pm 0.5$ & $28.3 \pm 0.9$ & $24.0 \pm 0.9$ & $27.8 \pm 0.5$ & $22.5 \pm 1.0$ \\
\hline
\end{tabular}

All the values are mean \pm standard deviation of three determinations. Mean \pm S.D. $\mathrm{mm}(\mathrm{n}=3)$;

$\mathrm{P}<0.05$

Table 5. MIC and MBC values of cinnamaldehyde (Cinn) and carvacrol (Carv)

\begin{tabular}{|c|c|c|c|c|}
\hline \multirow[t]{2}{*}{ Test Organisms } & \multicolumn{2}{|c|}{$\mathrm{MIC}(\%)$} & \multicolumn{2}{|c|}{ MBC (\%) } \\
\hline & Cinn & Carv & Cinn & Carv \\
\hline Staphylococcus aureus & 0.125 & 0.125 & 0.25 & 0.25 \\
\hline Escherichia coli & 0.5 & 0.5 & 1.0 & 1.0 \\
\hline Shigella dysenteriae -1 & 0.25 & 0.25 & 0.5 & 0.5 \\
\hline
\end{tabular}




\section{Discussion}

The results presented in Table 2 showed that the oils under investigation exhibited marked antibacterial activity as evidenced by their zones of inhibition. The findings of cinnamaldehyde correlated with the findings of Hoque. et al. $(2007)^{8}$ studied on essential oils of cloves and cinnamon against food borne pathogen and spoilage bacteria. The essential oils under this study consist of phenolic components, which render them effective against the tested microorganisms. This was confirmed by Farag et al. $(1989)^{32}$. The antibacterial property of carvacrol matched with that of the findings of Friedman et al. (2002) ${ }^{19}$ who worked on carvacrol and found the carvacrol exhibited significant bactericidal activities. These observations also correlated with Ultee et al. $(1998)^{33}$ who exhibited the antibacterial activity of carvacrol against foodborne pathogens.

The antibacterial activity of cinnamaldehyde and carvacrol was found at all temperatures employed $\left(25^{\circ}, 37^{\circ}, 50^{\circ}, 75^{\circ}\right.$ and 100 ${ }^{\circ} \mathrm{C}$ ) suggesting that cinnamaldehyde and carvacrol were not destroyed at high temperature even at $100{ }^{\circ} \mathrm{C}$ for $30 \mathrm{~min}$ treatment. A little increase in activity of both cinnamaldehyde and carvacrol was observed at $100^{\circ} \mathrm{C}$ which may be due to the partial exhaustion of solvent (ethanol) in oils at high temperature above $60{ }^{\circ} \mathrm{C}$. Similar type of findings was reported by Hoque. et al. $(2007)^{8}$.

The antibacterial activity of cinnamaldehyde and carvacrol against most of the tested organisms was slightly decreased at $\mathrm{pH} 5.0$, but increased at $\mathrm{pH} 7.0$ and 9.0 with maximum inhibition at $\mathrm{pH}$ 7.0. These findings supported the findings of Hoque et al. $(2007)^{8}$, they reported higher activity of cinnamon oil against cocktail of S. aureus at pH 7.0 compared to pH 5.0 and 9.0.

MICs of cinnamaldehyde and carvacrol were determined by the broth dilution method at $37^{\circ} \mathrm{C}$ and at $\mathrm{pH} 7.0$. MIC values of cinnamaldehyde against the test bacteria ranged between 0.125 and $1.0 \%$ and for carvacrol 0.125 and $0.5 \%$. The MIC of cinnamaldehyde showed the highest inhibition of $S$. aureus $(0.125$ $\%)$ and followed by $S$. dysentarae $(0.25 \%)$, K. rhizophila $(0.25$ $\%)$ and $V$. cholerae $(0.5 \%)$. However, lowest inhibition was found for $P$. aeruginosa $(1.0 \%)$. The MIC of carvacrol showed the highest inhibition for $S$. aureus $(0.125 \%)$, followed by $S$. dysentarae $(0.25 \%)$, K rhizophila $(0.25 \%)$ and $V$. cholerae $(0.25$ $\%)$.

\section{Conclusion}

The essential oil cinnamaldehyde and carvacrol possess antibacterial property that can be fruitfully used as antibacterial as alternatives of antibiotics to control foodborne pathogens and spoilage bacteria. These essential oils act through natural inhibitory mechanisms by either inhibiting or killing the pathogens completely. Cinnamaldehyde may be a better choice as preservatives for foods. In developing countries like Bangladesh, where spices are produced and used as food additives, their use as antibacterial agents and potential preservatives can be extremely useful without health risk.

\section{References}

1. Lopez CM, Nitisinprasert S, Wanchaitanawong $\mathrm{P}$ and Poovarodom N. 2003. Antimicrobial activity of medicinal plant extracts against foodborne spoilage and pathogenic microorganisms. Kasetsart J. Nat. Sci. 37: 460-467.

2. Jay JM. 2000. Modern Food Microbiology, $6^{\text {th }}$ Edn. Aspen Publishers, Ins., Maryland. P. 679.

3. Roy B. 2001. Fundamental Food Microbiology, $2^{\text {nd }}$ Edn. CRC Press, LLC, Florida, p. 562.

4. Mead PS, Slutsker L, Dietz V, McCaig LF, Bresee LS, Shapiro C, Griffin PM and Tauxe RV. 1999. Food related illness and death in the United States. Emerg. Infect. Dis. 5: 607-625.

5. Faruque SM, Chowdhury N, Kamruzzaman M, Shaft Ahmad Q, Faruque ASG, Salam MA, Ramamurthy T, Balakrish Nair G, Weintraub A and Sack DA. 2003. Reemergence of epidemic Vibrio cholerae 0139. Bangladesh - Res Emerg Infect Dis. 9: 1116-1122.

6. Taniya AJ, Kabir Y and Hoque MM. 2016. Occurrence of Emerging Food borne pathogens in first foods and its control by essential oils (EOs). J.Biod. Cons. Biores. Manag. 2(1): 13-22.

7. Hoque MM, Rattila S, Shishir MA, Bari ML, Inatsu Y and Kawamoto S. 2011. Antimicrobial activity of ethanol extract of Betel leaf (Piper betle L.) against some food borne pathogens. Bangladesh J. Microbiol. 28: 58-63.

8. Hoque MM, BariI ML, Inatsu Y, Juneja VYK and Kawampto S. 2007. Antibacterial Activity of Guava (Psidium guajava L.) and Neem (Azadirachta indica A. Juss.) Extracts against Food Borne Pathogens and Spoilage Bacteria. Foodborne Path and Dis. 4: 481-488.

9. Hoque MM, BariI ML, Inatsu Y and Kawampto S. 2006. Antibacterial activity of some Asian Spices and Herbs against Selected Potent Food Borne Pathogens and Spoilage Bacteria. Proceeding of the JapanBangladesh Joint International Conference on Microbiology Education and the Prospect of Japanese Collaboration in Education and Research. 2: 22-30 (Japan).

10. Nanasombat S and Loliasupthawce P. 2005. Antimi-crobial activity of crude ethanolic extracts and essential oils of spices against salmonellae and other cnterobacteria. KMITL Tech. J. 5: 527 -538.

11. Sanches NR, Garcia DA, Schiavini MS, Nakamura CV and Filho RPD. 2005. An evaluation of antibacterial activities of Psidium guajava (1). Brazilian Arch. Bio and Techiiol. 48: 429-436.

12. Nevas M, Korhonen AR, Lindtroru M, Turk-ki P, Korkeala H. 2004. Antibacterial efficiency of Finnish spices essential oils against pathogenic and spoilage bacteria. J. Food Prot. 67: 199-202.

13. Burt S. 2004. Essential oils: their antibacterial prop-erties and potential applications in foods-a review. Int. J. Food Microbiol. 94: 223-253.

14. Burt SA and Reinders RD. 2003. Antibacterial activity of selected plant essential oils against Escherichia soli 0157 : H7. Lett. Appl. Microbiol. 36: $162-167$.

15. Mitscher LA, Drake S, Golloapudi SR and Okwute SK. 1987. A modern look at folkloric use of anti-infective agents. J. Nat. Products. 50: 10251040 .

16. Zaika LL. 1988. Spices and herbs: their antibacterial activity and its determination. J. Food Saf. 23: 97-118.

17. Nirdiry ESJ. 1998. Structure-fungitoxicity relationships of the monoterpenoids of the essential oils of peppermint (Mentha piperita) and scented geranium (Pelargonium graveolens). J Essent Oil Res. 10: 628-631.

18. Stammati A, Bonsi P, Zucco F, Moezelaar R, Alakomi HL and von Wright A. 1999. Toxicity of selected plant volatiles in microbial and mammalian short-term assays. Food Chem Toxicol. 37: 813-823.

19. Frirdman M, Henika PR and Mandrell RE. 2002. Bactericidal activities of plant essential oils and some of their isolated constituents against Campylobacter jejuni, Escherichia coli, Listeria monocytogenes, and Salmonella enterica. J. Food Prot. 65: 1454-1560. 
20. Bari ML, Inatsu Y, Hoque MM and Kawamoto S. 2016. Use of cloves and cinnamon essential oil to inactivate Listeria monocytogenes in ground beef at freezing and refrigeration temperatures. LWT-Food Sci. and Technol. 74: 219-223.

21. Helander IM, Alakomi HL, Latva-Kala K, Mattila-Sandholm T, Pol I, Smid EJ, Gorirs LGM and Wright AV. 1998. Characterization of the action of selected essential oil components on Gram negative bacteria. J. Agric. Food Chem. 46: 3590-3595.

22. Bowles BL and Miller AJ. 1993. Antibacterial properties of selected aromatic and aliphatic aldehydes. J. Food prot. 56: 788-794.

23. Cox SD and Markham JL. 2007. "Susceptibility and intrinsic tolerance of Pseudomonas aeruginosa to select plant volatile compounds" J. Appl. Microbiol. 103 (4): 930-936.

24. Du Wx, Olsen CE, Avena-Bustillos RJ, McHugh Th, Levin CE and Friedman M .2008. "Storage Stability and Antibacterial Activity against Escherichia coli 0157:H7 of Carvacrol in Edible Apple Films Made by Two Different Casting Methods". J Agric. Food Chem. 56(9): 3082-3088.

25. Ultee A, Slump RA, Steging G and Smid EJ. 2000. Antimicrobial activity of carvacrol toward Bacillus cereus on rice. J. Food Prot. 63: 620-624.

26. Jorgensen JH, Turnide JD and Washington JA. 1999. Antibacterial susceptibility tests: dilution and disk diffusion methods. In: Murry P R, Pfaller MA, Tcnover F C, Baron E J, Yolken R H, editors. Manual of
Clinical Microbiology, 7 th ed. Washington DC, ASM Press. pp 15261543.

27. Lee, Ching-Fu, Chien-Kuo H and Jya-Li T. 2004. In vitro inhibitory activity of Chinese leek extract against Campylohacter species. Int. J. Food Microbiol. 94: 169-174.

28. Bauer AW, Kirby WMM, Sherris JC and Truck M. 1066. Antibiotic sensitivity testing by a standardized single disk diffusion method. Am. J. Clin. Pathol. 45: 157-160.

29. Shabata K, Yho A and Hengo AY. 1995. Bacterial activity of spices antimicrobial agent against Helicobacter pylori under acidic condition, Antimicrob. Agents. Chemother. 39: 1295-1299.

30. Ohono T, Kita M, Yamaka Y, Imamura T, Mitsufuji S, Kodama T, Kashima $\mathrm{K}$ and Imanishi J. 2003. Antimicrobial activity of essential oils against Helicobacter jejuni. Helicobacter. 8: 207-215.

31. Sengul MHO, Adeguzel A, Sahin F, Kara AA, Karkan I and Gulluce M. 2005. Antimicrobial effects of Verscum georgicum Bentham extract. Tukki J. Biol. 29: 105-110.

32. Farag RS, Daw ZY, Hewedi FM and El-Baroty GSA. 1989. Antimicrobial activity of some Egyptian spice essential oils. J. Food Prot. 52: 665-667.

33. Ultee A, Gorris LMG and Smid EJ. 1998. Bactericidal activity of carvacrol towards the food-borne pathogen Bacillus cereus. J. Appl. Microbiol. 85: $211-218$. 